\title{
JOHN LOCKE: POR UMA EDUCAÇÃO LIBERAL
}

\author{
Ronaldo Aurélio Gimenes Garcia \\ Secretaria de Estado da Educação de São Paulo - SEESP
}

\section{RESUMO}

John Locke foi um dos fundadores do pensamento liberal. Suas idéias tiveram uma repercussão muito grande entre os iluministas franceses e contribuíram para a derrocada do absolutismo na Europa. Além de filósofo e médico, Locke também foi preceptor de jovens filhos da burguesia fundiária. A partir dessas experiências deixou algumas cartas, que reunida, permitem compreender quais eram as principais propostas do filósofo para a educação. Às crianças e jovens do povo estava reservada uma escola profissionalizante e de curta duração. Para as camadas prósperas, o tempo de escolarização era maior e privilegiava o ensino das ciências e da matemática. As ideias do filósofo de Bristol tiveram influências em diferentes épocas e lugares, chegando até ao Brasil.

Palavras-chave: John Locke; liberalismo; história da educação; escola; ensino.

\section{ABSTRACT}

\section{JOHN LOCKE: FOR A LIBERAL EDUCATION}

John Locke was as one of the founders of the liberal thought. Its ideas had a very great repercussion between the French illuminists and had contributed for the destruction of the absolutism in the Europe. Beyond philosopher and doctor, Locke also was the young teacher children of the agrarian bourgeoisie. From these experiences it left some letters that congregated allow to understand which were the main proposals of the philosopher for the education. To the children and young of the people they were reserved a professionalizing school and fast duration. For the prosperous layers, the school time was bigger and privileged the education of sciences and the mathematics. The ideas of the philosopher of Bristol had had influences at different times and places arriving until the o Brazil.

Keywords: John Locke; liberalism; history of education; school; learning

\section{Introdução}

O objetivo deste artigo é discutir alguns aspectos do pensamento do filósofo inglês John Locke, concernentes à educação. Não pretendemos aqui fazer um estudo exaustivo sobre tema, uma vez que esse não é o propósito do nosso trabalho. Queremos iniciar algumas discussões que poderão ser, em outras ocasiões, aprofundadas. No Brasil localizamos poucos estudos sobre a obra educacional de Locke, o que representa uma vantagem para a produção de pesquisas sobre o tema. Por outro lado também, pode dificultar a investigação, dado reduzido número de estudos em língua portuguesa.

A principal obra de Locke sobre o tema foi inicialmente publicada em 1693, sob o título Alguns pensamentos sobre a educação. Trata-se de um conjunto de cartas publicadas em que o citado autor discutiu sua experiência enquanto preceptor de vários jovens nobres e burgueses da Inglaterra. O mencionado livro ainda foi traduzido em partes para o português ${ }^{1}$. Existe uma tradução para o espanhol intitulada Pensamientos sobre la educación, que utilizamos nesse artigo. Além desse estudo de Locke trabalhamos também com $O$ segundo tratado sobre o governo de 1690 e o Ensaio acerca do entendimento 
humano, editado no mesmo ano. Recorrer a outras obras do autor foi importante para compreendermos melhor o desenvolvimento do seu raciocínio, bem como reconhecer a influência da sua concepção filosófica e política no seu modelo de educação.

Antes propriamente de adentramos no cerne da questão, achamos importante conhecer um pouco da história da Inglaterra do século XVII e o envolvimento de John Locke com a problemática de seu tempo. Essa constituirá a primeira parte do texto, posteriormente iremos estudar, em termos gerais, as teorias filosóficas de Locke, e por último, suas contribuições para a educação e seu modelo de ensino e possíveis conclusões.

\section{Uma Inglaterra revolucionária}

No século XVII, entre os anos de 1640 e 1660, a Inglaterra viveu um período de intensas lutas e revoltas que marcam a ascensão da burguesia enquanto classe dominante. Entre os vários episódios revolucionários que caracterizam esse período, podemos citar: $\mathrm{A}$ Grande Revolução; A Revolução Puritana; A Guerra Civil; A República de Cromwell e a Restauração. Para entender os motivos desta revolução, que se divide em várias fases, é preciso conhecer um pouco mais da economia e da política inglesa daquele período.

Desde o século XV a Inglaterra já possuía uma considerável indústria têxtil que operava com a lã fornecida pela criação de ovelhas. Na realidade eram manufaturas que reuniam vários artesãos em um mesmo espaço, sendo que os mesmos dividiam entre si as tarefas de confecção dos tecidos de lã. Ainda não havia a utilização de máquinas o que iria ocorrer somente na segunda metade do século XVIII.

A indústria têxtil, para fugir às restrições impostas pelas corporações urbanas, aferradas a seus privilégios e tradições, havia se espalhado pelas aldeias dando início ao chamado sistema de produção doméstica (puttingout). Neste sistema, embora a técnica de produção permanecesse ainda artesanal, existia já uma divisão (especialização) do trabalho e o capital dominava a produção (o produtor perdeu sua independência, tornando-se um tarefeiro assalariado) (FLORENZANO, 1986, p. 69).

O caso inglês fugia um pouco do modelo dos países europeus do continente. Evidentes elementos do capitalismo conviviam com as características de uma sociedade feudal. Embora o comércio fosse o carro-chefe da economia, a indústria e a agricultura apareciam como atividades em constante expansão. A nobreza que nos países europeus continentais era um resquício evidente do sistema feudal, na Inglaterra estava dividida em duas camadas. A alta nobreza que possuía um estilo de vida mais próximo daquele das cortes da França, da Rússia e da Prússia e a pequena e média nobreza que desconsideravam os laços de sangue, pois muitos de seus membros advinham de diferentes estamentos sociais (comerciantes, manufatureiros, traficantes e outros). Possuir terras na Inglaterra nesse período era um excelente investimento para vários setores, inclusive para a burguesia.

Ao adquirir terras o indivíduo passava a fazer parte da gentry. Assim distinguia-se dos plebeus, uma vez que poderiam ter o direito de usar um brasão. O gentleman, como passava a ser chamado o membro da gentry, indicava a origem social de muitos dos alunos de John Locke e das famílias para as quais serviu. Tratava-se de uma camada de proprietários rurais que embora almejassem ter um estilo de vida próximo da aristocracia, tinham uma atitude claramente capitalista (FLORENZANO, 1986).

Os cercamentos das propriedades (enclosures) iniciados no século XVI condenaram à miséria e à fome a camada da população constituída pelos pequenos camponeses 
arrendatários e jornaleiros. Praticados pelo Parlamento, com o apoio dos proprietários, os cercamentos acabavam com as terras comunais e com a possibilidade dos pequenos agricultores e criadores de ovelhas desempenharem suas atividades. $\mathrm{O}$ resultado foi a eliminação da camada dos camponeses da Inglaterra. Esta massa de expropriados irá se constituir em força de trabalho barata para os primeiros tempos da revolução industrial.

Outra peculiaridade importante da Inglaterra em relação aos outros países europeus era a presença do Parlamento. Desde o século XIII o Parlamento que representava as diferentes camadas proprietárias (alta nobreza, gentry, clero e burguesia), tinha a função de votar as leis e de aprovar os impostos. Durante o período da Reforma e da criação da Igreja Anglicana pelo rei Henrique VIII e sua herdeira Elisabeth I, o Poder Legislativo representou um importante papel de sustentação para a implantação da nova religião oficial do Estado. Com isso, a referida instituição política ganhou mais poder e aumentou o número de deputados de 300 para 500 membros.

A reforma beneficiava a todos (governo e camadas dominantes), pois conseguia diminuir o poder da Igreja Católica no país, onde possuía mais de um terço das propriedades agrícolas (Florenzano, 1986). Além disso, a desapropriação das terras e sua posterior venda, interessava diretamente a gentry. É curioso notar que a criação de uma igreja nacional inglesa não representou o fim dos conflitos religiosos naquele país. Grupos católicos resistiram e os protestantes puritanos, que cresceram muito na ilha, tiveram uma forte influência no Parlamento.

Jaime I e seu filho e sucessor Carlos I, que governaram a Inglaterra após o reinado de Elisabeth I, tentaram reproduzir o que vinha acontecendo nas principais monarquias européias, ou seja, a prática do absolutismo. Os monarcas tentaram diminuir o poder do Parlamento, criaram pesados impostos alfandegários, organizaram monopólios e procuraram controlar determinados setores industriais. Jaime I ainda conseguiu concluir o seu governo, mas seu filho, Carlos I, mergulhou o país em uma profunda crise que levou à revolução.

Nos últimos anos de 1630, a política absolutista de Carlos I tinha conduzido a nação a um beco sem saída. À revolta política crescente, somava-se, para agravá-la, uma crise econômica (geral a toda a Europa) responsável, a partir de 1620, pela retração no comércio de exportação e na manufatura de tecidos. Estas dificuldades prosseguiram por toda a década seguinte e agravaram a situação financeira da Monarquia (FLORENZANO, 1986, p. 93).

O resultado do conflito entre Carlos I e o Parlamento foi uma terrível guerra civil que terminou em 1649. O rei foi executado e os parlamentares conseguiram a vitória. A República foi instalada sob a direção de Cromwell que implantou uma ditadura. Ele contou com declarado apoio do exército e da burguesia puritana. Durante seu governo, por meio do Ato de Navegações, conseguiu destruir a hegemonia dos holandeses nos mares e transformou a Inglaterra na maior potência naval e comercial do mundo. No entanto a República não resistiu após a morte de Cromwell. Uma nova guerra civil levou a nação de volta à Monarquia e a dinastia dos Stuart retoma o poder. Esta é a chamada fase da Restauração.

Com o período da Restauração os conflitos entre o Parlamento e o rei recomeçaram. De um lado o governo pró-católico de Carlos II e de outro os membros do Poder Legislativo. Neste período o Parlamento se dividiu entre dois partidos: os Tories (conservadores) e os Whings (liberais). A crise chegou ao seu ponto máximo no governo de Jaime II. Tories e Whings se uniram com Guilherme de Orange que estava na Holanda e 
que era genro de Jaime II. Organizaram uma conspiração que levou a deposição do antigo rei católico e a instalação de Guilherme no poder.

A Revolução Gloriosa estava assim concluída com a vitória dos liberais. Por meio do Bill of Rights (Carta de Direitos) o novo rei jurava respeitar as decisões do Parlamento. Desde dessa época até os dias de hoje, o Legislativo exerce uma autonomia legal frente à realeza inglesa.

\section{Locke: seu tempo e suas idéias}

John Locke nasceu em 1621 nas proximidades da cidade de Bristol na Inglaterra. Sua família era constituída de burgueses puritanos ligados ao comércio. Seu pai lutou a favor do Parlamento na revolução civil de 1648. Desde cedo o filósofo do liberalismo, como ficou conhecido Locke, recebeu uma forte influência das idéias do protestantismo puritano e da aversão ao absolutismo monárquico.

Locke estudou na Westminster School e em 1652 foi para o Crist Church College de Oxford. De estudante passou à condição de professor universitário e permaneceu ligado a Oxford até o ano de 1684. Realizou diversos tipos de estudos como os de química, de meteorologia, chegando até a discussão da teologia. Apesar de tantos e variados interesses, Locke se dedicou profissionalmente à medicina. Começou a desenvolver uma ciência experimental que deixava de lado os dogmas dos médicos da Antiguidade, para elaborar uma prática mais empírica baseada em hipóteses e na observação dos pacientes.

Locke, ao lado de Francis Bacon, foi um dos principais pensadores da corrente empirista. Desiludido com as explicações dos escolásticos que concebiam o conhecimento como algo inato, Locke propunha que o que sabemos chega até nós através dos nossos sentidos, ou seja, da nossa experiência com o mundo natural que nos cerca.

Como médico Locke serviu a Antony Sahley Cooper, lorde e conde de Shaftesbury. Com o tempo ganhou a confiança do nobre que o nomeou como seu assessor particular. A partir desse período começou a conviver nos altos círculos de intelectuais e políticos. Também nessa época iniciou a redação do Ensaio acerca do entendimento humano.

O conde de Shaftesbury ocupou vários cargos importantes enquanto representante do Parlamento, porém os conflitos entre ele e o rei Carlos II de tendência absolutista aumentavam a cada dia. Em 1675 o conde foi destituído de todos os seus cargos e obrigado a retirar-se para França. No ano seguinte o referido conde retorna à Inglaterra e volta a exercer suas atividades políticas. Segundo Mello (2002), o nobre tornou-se o mentor político de Locke e o influenciou muito na sua formação liberal.

Em 1681 o conde de Shaftesbury foi acusado de conspirar contra o rei Carlos II e Locke de colaborar com seu mentor. Ambos foram exilados na Holanda. Um ano depois o nobre faleceu e Locke só retornou à Inglaterra após a queda de Jaime II em 1989. Naquele mesmo ano e no seguinte publicou os Dois tratados sobre o governo civil e o Ensaio acerca do entendimento humano, que demorou 20 anos para ser concluído. Em 1704, no dia 27 de outubro, Locke morreu.

O pensamento do filósofo inglês refletiu muito da sua condição social e da sua experiência política em uma Inglaterra ainda semifeudal que caminhava a passos largos para o modelo capitalista. Embora Locke ainda não tivesse condições de fazer muitas afirmações sobre o novo modo de produção, uma vez que muitos elementos da sociedade do capital estavam presentes apenas de forma embrionária, ele percebe uma transição entre o mercantilismo e as novas práticas econômicas do capitalismo. A luta do Parlamento para limitar o poder dos monarcas era, em última instância, uma tentativa bem sucedida de 
superar os resquícios do sistema feudal que dificultava a livre expansão das forças produtivas.

Ao lado de Rousseau e Hobbes, Locke pertence à linha filosófica do jus naturalismo, ou também conhecida como teoria dos direitos naturais. Para esses pensadores os homens que viviam em estado de natureza realizaram a passagem para a sociedade civil através de um contrato social. Existe, porém uma diferença marcante entre Hobbes e Locke. Para o primeiro o mundo da natureza era dominado por um estado constante de guerra em que os mais fracos eram devorados pelos mais fortes.

Locke concebia um estado de natureza originalmente equilibrado, os homens possuíam em si a capacidade de criar normas, julgar e condenar, ou seja, já praticavam os três poderes do Estado Civil (Poder Executivo, Legislativo e Judiciário). Nesse estágio natural prevalecia a igualdade e a liberdade. Os indivíduos já eram dotados de razão e praticavam a propriedade privada que era conquistada pelo trabalho. A vida, a liberdade e a propriedade dos bens eram direitos naturais dos seres humanos.

O filósofo de Bristol era um profundo estudioso de arqueologia e muito curioso sobre a origem e desenvolvimento da espécie humana. Por isso afirmava que os grupos humanos em diferentes épocas passaram do estágio da natureza para a vida em sociedade. O surgimento do Estado ocorre quando as relações humanas se tornam mais complexas e a escassez de bens leva à necessidade da economia.

Em Locke, o contrato social é um pacto de consentimento em que os homens concordam livremente em formar a sociedade civil para preservar e consolidar ainda mais os direitos que possuíam originalmente no estado de natureza. No estado civil os direitos naturais inalienáveis do ser humano à vida, à liberdade e aos bens estão melhor protegidos sob o amparo da lei, do árbitro e da força comum de um corpo político unitário (MELLO, 2002, p. 86)

Com o pacto social (ou contrato social) os direitos não deixavam de ser naturais, mas passavam a ser socialmente naturais. As diferenças sociais de acordo com Locke não deviam interferir nos direitos naturais. É interessante notar que o contrato social não superou uma contradição latente, pois o homem não deixou de ter aqueles poderes (de julgar, legislar e executar) que faz parte dos seus instintos, ele apenas os delegou a um Estado. Nascia aqui a contradição entre o público e o privado que passava a fazer parte da nossa forma de existir.

O Estado nascia na sociedade civil e a ela deveria se submeter. Ele seria visto como um meio que sociedade usou para se desenvolver. Locke considerava que de todos os poderes, o Legislativo era o mais importante, pois os demais a ele devem se submeter. Era a melhor forma de evitar o abuso de poder. Para o filósofo não importava muito a forma de governo, mas o lugar que a capacidade de legislar ocupava. Existe aqui uma nítida relação com a situação da Inglaterra e com a luta do Parlamento e da coroa durante a Revolução Gloriosa.

O pai do pensamento liberal também pensou na hipótese do Legislativo e ou do Executivo violar o pacto social, usurpando o poder em benefício próprio ou desrespeitando o direito de propriedade. Nestes casos o autor afirmava que seria legítimo o uso da força por parte do povo, como forma de lutar contra a tirania de um governo. Resistir a um governo corrupto ou à invasão de uma nação estrangeira era justificável. Na concepção de Locke era o uso da violência contra o que ele reconhecia ser uma violência ainda maior. 


\begin{abstract}
Neste ponto é provável que formulem a pergunta comum: Quem julgará se o príncipe ou o legislativo agem contrariamente ao encargo recebido? [...] A isto respondo: o povo será o juiz; porque quem poderá julgar se o depositário ou o deputado age bem e de acordo com o encargo a ele confiado senão aquele que o nomeia, devendo, por tê-lo nomeado, ter ainda poder para afastá-lo quando não agir conforme seu dever? Se isto for razoável no caso particular de homens privados, por que seria de outra forma no de maior importância que afeta o bem estar de milhões, e também quando o mal, se não for preventivo, é maior e a reparação muito difícil, dispendiosa e arriscada? (LOCKE, 2002, p. 110).
\end{abstract}

Ao lado de sua contribuição no campo de formulação das teorias do liberalismo que outros autores como Adam Smith e David Ricardo aprofundaram posteriormente, Locke também se preocupou com a origem do conhecimento. Como representante do empirismo, o filósofo inglês negava que as idéias que temos sobre as coisas do mundo sejam inatas, como pensava Descartes. Ainda segundo o pensador de Bristol, a crença na existência das concepções inatas desconsiderava a especulação e tomava o caráter de algo dogmático e definitivo. Para Locke era fundamental a ação prática do homem sobre a natureza para desvendá-la e compreendê-la. Assim o filósofo inglês afirmava que nossas idéias surgem de nossa experiência através dos sentidos. Nascemos como um papel em branco que aos pouco vai sendo impresso à medida que vivenciamos novas experiências.

Suponhamos, pois que a mente é, como dissemos, um papel branco, desprovida de todos os caracteres, sem quaisquer idéias; como ela será suprida? De onde lhe provém este vasto estoque, que a ativa e que a ilimitada fantasia do homem pintou nela com uma variedade quase infinita? De onde apreende todos os materiais da razão e do conhecimento? A isso respondo, numa palavra, da experiência. Todo o nosso conhecimento está nela fundado e dela deriva fundamentalmente o próprio conhecimento (LOCKE, 1999, p.83).

A partir dessas rápidas palavras sobre alguns dos principais aspectos do pensamento de John Locke é possível pensar um pouco no modelo de educação que derivaria de um Estado baseado no consenso entre os homens e na subordinação de todos os poderes ao Legislativo. Além disso, deveria haver um respeito aos direitos naturais do homem (liberdade, vida e propriedade). As diferenças entre os seres humanos deveriam ser pensadas enquanto algo naturalmente dado. O Estado que derivou do pacto social deveria portar-se como um juiz imparcial, não se preocupando com a condição social dos seus cidadãos e interferindo o mínimo possível na livre iniciativa (LAGO, 2002).

\title{
O pensamento de Locke a respeito da educação
}

Para o filósofo de Bristol a preocupação maior era com a educação dos gentlemen, ou seja, os filhos da gentry (parte da nobreza inglesa de origem burguesa proprietária de terras). Quanto aos pobres, na opinião do filósofo inglês, deveriam receber uma formação profissional que fornecesse mão de obra mais qualificada para as indústrias têxteis da Inglaterra. Embora não ignorasse a existência dos mais pobres, Locke não estava interessado nas causas das desigualdades sociais.

Segundo Manacorda (1994), existe no pensamento de Locke um considerável desprezo pela cultura e em contrapartida uma valorização do jogo, da utilidade prática das coisas, da persuasão racional e do autogoverno "que objetiva não a variedade de 
conhecimentos, mas a liberdade do pensamento" (MANACORDA, 1994, p.226). A educação física e o trabalho são mecanismos importantes para a educação dos delinquentes e dos pobres. A cultura e a instrução deveriam estar em segundo plano, na educação das camadas mais populares.

A educação provocava a diferença entre os indivíduos, mas apesar de reconhecer isto, Locke não estava preocupado com ela. O pensador estava convencido que o mundo estava bem como se apresentava, não existia preocupação em modificar a estrutura social.

Nadie está obligado a saberlo todo. El estudio de las ciencias en general es asunto de aquellos que viven con acomodo y que disponen de tiempo libre. Los que disponen de empleos particulares deben entender sus funciones; y no es insensato exigir que piensen y razonen solamente sobre lo que forma su ocupación cotidiana (LOCKE, 1986, p.18) ${ }^{2}$.

Aos filhos da nobreza e da burguesia deveriam ser ensinados os conteúdos mais refinados, para os menos favorecidos, apenas o necessário para o desempenho de suas funções. Mesmo quando os nobres e burgueses aprendiam alguma arte manual era apenas uma forma de desenvolver a sua habilidade ${ }^{3}$. Consta que Locke tinha uma verdadeira aversão às escolas públicas, sua experiência nesta área dizia respeito à educação dos gentlemen.

Outro aspecto relevante do pensamento de Locke sobre a educação era a sua oposição a toda forma de castigo físico. Segundo o filósofo, o aspecto rebelde e antissocial da criança não poderia ser tomado por ele mesmo. Isso tinha mais a ver com a lei natural que prevalecia antes do contrato social. A educação era uma forma de renunciar ao estado natural, daí o seu caráter de disciplina e severidade. O castigo só deveria ser usado para a formação de costumes. Mesmo assim somente quando o convencimento pela razão falhava.

O propósito da educação era dominar o estado de natureza que existe em toda criança e que os homens abandonaram através do contrato social. Por esse motivo a principal tarefa da educação, segundo Locke, não era tanto a instrução e a transmissão dos conhecimentos acumulados pela humanidade, mas a formação de costumes por meio da disciplina e da severidade. No entanto o emprego dos castigos físicos deveria ser moderado e para a correção do comportamento inadequado do educando.

O professor nesse modelo de escola deveria conhecer a fundo seu aluno e sua natureza, a fim de aproveitar melhor suas habilidade e tendências. Mais uma vez podemos perceber uma constante preocupação do autor em evitar esforços desnecessários na educação dos jovens e crianças. Segundo Enguita (1986), isso revelava o aspecto burguês do pensamento do filósofo parlamentarista, em que a economia de tempo e esforço era fundamental para garantir a acumulação. Em uma Inglaterra que se preparava para a revolução industrial, este comportamento constituía um tipo de mentalidade capitalista em gestação.

Quienquiera que se ocupe de la educación de los niños deberá estudiar su naturaleza y su capacidad, ver [...] cúal es su inclinación dominante, [...] considerar lo que les falta, [...] sacar el mejor partido posible de lo que la naturaleza ha puesto en los niños, prevenir los vicios y los defectos a los que tal cual temperamento más se inclina y procurar todas las ventajas que sea capaz de recibir. Se deberá, digo, llevar el genio natural de cada niño tan lejos como pueda llegar. Pero intentar unir a lo que ya tiene algo enteramente diferente es desperdiciar su esfuerzo (LOCKE, 1986, pp. $159-160)^{4}$. 
Quando se referia ao ensino da língua, Locke defendia que as crianças deveriam estudar primeiro a língua materna para somente depois partir para outros idiomas. O latim, por exemplo, deveria ser ensinado apenas aos jovens de famílias mais abastadas. Para o indivíduo comum do povo, ficaria o estudo mais utilitário da língua nativa. $\mathrm{O}$ ideal seria que a escola ensinasse a ler e escrever bem, desenvolver cálculos matemáticos e aprender coisas que fossem úteis para a vida da maioria da população e das profissões. Qualquer que fosse o ensino de idiomas, de acordo com o pensador inglês, deveria prevalecer a conversação, embora não desconsiderasse a aprendizagem da gramática.

No século XVII a educação na Europa Continental ainda vivia sob a influência da proposta do Renascimento, que privilegiava o estudo do latim, do grego, da arte e do humanismo em geral. Na contramão desta tendência e preocupado com a formação dos líderes da futura camada dominante, Locke afirmava que o gentleman deveria aprender lógica, retórica e gramática, porém sem perder muito tempo com estes conteúdos. O jovem da nobreza e da burguesia iria aprender de maneira mais longa e aprofundada as ciências naturais e experimentais (física, química, biologia), incluindo aqui também a matemática. Além disso, os estudos de moral, metafísica e teologia não poderiam ser excluídos.

Um jovem das camadas proprietárias seria formado para obter uma determinada consciência crítica, autonomia intelectual e de juízo, ou seja, que soubesse transmitir e discutir suas idéias com propriedade. Por outro lado, também era importante saber analisar criticamente a opinião dos outros, incorporando ou recusando-a de acordo com seus interesses e estratégias.

De acordo com o pensamento de Locke, a principal função da educação de um gentleman era criar no educando o hábito de administrar bem o seu esforço, evitando o desgaste de tempo e força em vão. Nas palavras do filósofo o objetivo maior do homem era a busca da felicidade e evitar a todo custo a miséria, entendendo a primeira como tudo aquilo que agrada ao espírito. $\mathrm{O}$ que incomoda e perturba o indivíduo teria a ver com a infelicidade. "Consideraré, por consiguiente, como uma misión, el buscar la satisfacción y el deleite y evitar la inquietud y la incomodidad; tener tanto de lo primero y tan poco de lo segundo como sea posible" (LOCKE, 1986, p. 20) ${ }^{5}$.

Enquanto havia uma preocupação mais detalhada com a educação dos filhos dos burgueses, restava às crianças pobres descendentes de camponeses expulsos da terra uma escola de rígida disciplina voltada para o trabalho. Este seria o projeto de Locke para a educação popular de massas.

Si se encuentra a un niño o a una niña, menores de catorce años de edad, mendigando fuera de la parroquia en que habitan, si lo hacen dentro de una distancia de cinco millas de dicha parroquia, serán enviados a la Escuela más próxima, y allí serán azotadas y aplicados al trabajo hasta la tarde, para ser despedidos con tiempo suficiente para llegar a su lugar antes de la noche. $O$, si viven más allá de cinco millas del lugar en que se les sorprende mendigando, serán enviados a la casa de corrección más próxima, y allí permanecerán aplicados al trabajo seis semanas y aun las sesiones próximas después de terminarse las seis semanas (LOCKE, 1986, p. 21) ${ }^{6}$.

Antecipando-se ao seu tempo, Locke já concebia um modelo de educação pensando no mundo do trabalho. Para os filhos dos camponeses expropriados de suas terras, que como os pais passavam a mendigar para sobreviver, restava uma escola de formação de mão de obra que fornecesse trabalhadores mais qualificados e já disciplinados para o 
mundo fabril em formação na Inglaterra do século XVII. Mesmo sem uma estrutura de classes capitalista que só irá ocorrer em alguns países no final do século XIX o pai do pensamento liberal já propunha um tipo de ensino diferenciado para as camadas proprietárias e para as trabalhadoras. Sendo que, enquanto para os nobres e burgueses havia uma preocupação com a formação de um espírito crítico e autônomo, para os trabalhadores restava uma educação rígida, de valorização das artes mecânicas e de adaptação aos interesses do mercado. Uns eram ensinados para mandar e os demais para obedecer sem questionar.

A educação era uma forma de diferenciar as pessoas. Isto estava muito claro para Locke. Se hoje há um discurso influenciado pelas idéias neoliberais, afirmando que a educação é imprescindível para a sobrevivência do indivíduo no mercado de trabalho, o pensador de Bristol a via como elemento importante na conquista e manutenção do poder.

Pienso que puede afirmarse que de todos los hombres con que tropezamos, nueve partes de diez son lo son, buenos o malos, útiles o inútiles, por la educación que han recibido. Esta es la causa de la gran diferencia entre los hombres. Las menores y más insensible impresiones que recibimos en nuestra más tierna infancia tienen consecuencias muy importantes y duraderas (LOCKE, 1986, pp. 31-32) ${ }^{7}$.

É preciso esclarecer aqui que o termo educação para Locke não se restringe à escola apenas. Estava implícito em suas palavras que a família também era responsável pela educação de seus filhos. A escola iria continuar a tarefa da família de moldar o aluno aos costumes e princípios morais da sociedade. Podendo inclusive usar os castigos físicos, caso fossem necessários. Além disso, caberia à instituição escolar zelar pela formação intelectual do gentleman valorizando e estimulando a autonomia, o espírito crítico e a experiência científica como método de ensino-aprendizagem. Havia, portanto uma clara recusa a um modelo de ensino dogmático centrado apenas na gramática, no latim e na retórica.

Como os pensamentos de Locke sobre a educação não se restringiam apenas ao meio escolar, suas orientações incluíam principalmente a saúde do educando. As práticas ao ar livre, a alimentação correta e o constante contato com a água (natação) eram, para o médico-filósofo, indispensáveis para a formação de um homem dinâmico que tinha uma missão de intervenção no mundo. Havia uma recomendação de que as mães e serviçais não mimassem muito a criança, pois um gentleman deveria desde a mais tenra idade aprender a endurecer para enfrentar melhor os desafios da posição que iriam ocupar.

Que la salud es necesaria al hombre para el manejo de sus negocios y para su felicidad propia; que una constitución vigorosa y endurecida por el trabajo y la fatiga es útil para una persona que quiere hacer un papel en el mundo, es cosa demasiado obvia para que necesite ninguna prueba (LOCKE, 1986, p. 35) ${ }^{8}$.

Existia aqui uma clara defesa do mundo do trabalho como elemento primordial para a conquista e transformação da realidade. Locke se antecipou a Adam Smith, David Ricardo e Karl Marx ao colocar o trabalho como meio indispensável para a aquisição da propriedade. Ao fazer isto o pensador parlamentarista, já estava vislumbrando uma sociedade muito diferente da que prevalecia na maioria dos países europeus, onde o comércio, a indústria e outras ocupações próprias da burguesia eram vistas como atividades degradantes e indignas de um nobre. Tal mentalidade surgiu na antiga Roma que associava o trabalho a figura do escravo. Essas ideias resistiram durante muitos séculos no 
Velho Continente e chegaram aos diversos países de colonização ibérica trazidas pelos colonizadores e ainda está presente na nossa cultura. Talvez esteja aqui uma das possíveis explicações para o nosso atraso no processo de industrialização e modernização.

Retomando as discussões sobre o pensamento educacional de John Locke, vamos perceber que tão importante como cuidar da saúde física do educando, era contribuir na formação moral dele.

Como la fortaleza del cuerpo consiste principalmente en ser capaz de resistir la fadiga, lo mismo ocurre con la del espíritu. Y el gran principio o fundamento de toda virtud y merito estriba en esto, en que un hombre sea capaz de rehusarse la satisfacción de sus propios deseos, de contrariar sus propias inclinaciones y seguir solamente lo que su razón le dicta como lo mejor, aunque el apetito le incline en otro sentido (LOCKE, 1986, p. 66) ${ }^{9}$.

Ao tratar da formação moral do gentleman podemos perceber que o filósofo não fazia nenhum apelo explícito que fosse embasado em algum princípio religioso ou bíblico, como vemos em muitos pensadores da educação nesta época, como foi o caso de Comênio. No entanto parecia que houve a troca de um argumento do tipo resistir ao pecado da carne em nome da fé e da consciência religiosa, por um outro que tinha a razão como condutora da virtude e dos bons costumes. O modelo ideal de um nobre ou burguês para o pensador inglês, era um indivíduo rígido consigo mesmo, que soubesse esquivar-se de suas tendências devassas em nome de um objetivo terreno. Não com a intenção de salvação e de fortalecimento de sua fé, mas preocupado em conter os seus instintos, a fim de ajudar na sua tarefa de acumulação e de condutor das atividades produtivas.

Por outro lado, não podemos esquecer que Locke era um protestante puritano e como tal trouxe alguns aspectos de sua crença religiosa para a formulação do projeto educacional. Em última instância, controlar os desejos e os impulsos internos era também uma forma de agradar a Deus e dessa forma estar mais próximo d'Ele. Para os puritanos não existia uma separação entre a prosperidade material e a prática religiosa. A adoção de rígidos hábitos de conduta era um meio de somar riquezas e ao mesmo tempo zelar pela salvação da alma. Por esse motivo também havia toda uma preocupação com a educação moral como meio de fundir hábitos saudáveis nas crianças e jovens. Embora se respeitasse o aluno como um ser racional, Locke falava mesmo da necessidade imprescindível de inculcar nas crianças os valores e virtudes, pois caso contrário, o resultado seria a formação de indivíduos incapazes de ter o controle de si próprios e, portanto, propícios a desrespeitar a vontade e o domínio dos outros.

Este método de enseñar a los niños mediante la práctica repetida, y la realización de la acción misma una y otra vez, bajo la mirada y la dirección del tutor, hasta conseguir el hábito de hacerlo bien, y no mediante reglas confiadas a su memoria, tiene tantas ventajas, por cualquier lado que se le considere, que no puedo menos de admirarme (si pueden admirar las malas costumbres en cualquier cosa) de que llegue a olvidarse tanto (LOCKE, 1986, p. 89) ${ }^{10}$.

Embora admitisse a prática dos castigos físicos, Locke afirmava que eles deveriam ser moderados e adequados à situação que se quer empregá-los. O excesso de punições ao invés de ajudar a moldar o indivíduo, pode gerar um efeito ao contrário. $\mathrm{O}$ uso da força deve ser utilizado em último caso para ajudar o jovem ou a criança a controlar o seu estado de natureza que tende a se sobrepor à vontade dos demais. Um indivíduo constantemente 
açoitado acabava levando ao surgimento de um ser medroso, servil e incapaz de defender os seus pontos de vista. O próprio autor reconhecia que um tipo de educação assim, era mais prejudicial do que benéfica.

Esta clase de castigos no contribuyen en absoluto a dominar nuestra propensión natural a la indulgencia corporal y al placer presente, y a evitar al dolor a toda costa; por el contrario, la aumentan y fortifican en nosotros la disposición de donde brotan todas las irregularidades de la vida (LOCKE, 1986, p 77) ${ }^{11}$.

Mais adiante em suas análises o pensador de Bristol afirmava que o excesso de punições acaba por provocar um comportamento servil e dissimilado que apenas disfarçava e escondia uma moral corrompida do educando.

Si prevalece la severidad llevada a sus últimos límites y cura por el momento un carácter destemplado, pone en su lugar una enfermedad peor todavía y mas peligrosa, que es la de quebrar los resortes de su espíritu. Entonces, en lugar de un joven turbulento, tendréis una criatura sin energía que, aun cuando, por su sobriedad artificial guste a las gentes superficiales que quieren a los niños enmohecidos e indolentes, porque no hacen ningún ruido ni causan ninguna molestia, ni dejará de parecer a sus amigos un ser incómodo y que, en efecto, durante toda su vida será un ser inútil para sí mismo y para los demás (LOCKE, 1986, p. 78) ${ }^{12}$.

Não resta dúvida que aqui Locke estava preocupado em formar um gentleman e, para tanto, um ser humilhado e que perdeu a confiança em si próprio, não seria capaz de conduzir com autonomia os seus negócios. Por outro lado, era uma antecipação daquilo que a psicologia iria descobrir no século XX. A constante vigilância sobre o indivíduo gerava seres dependentes, infelizes que embora aparentemente disciplinados, vivenciavam profundos dramas pessoais. Rompeu-se com a falsa ideia de que o aluno calado, passivo diante do conhecimento que lhe era apresentado, era uma garantia de aprendizagem, como defendiam as escolas monásticas. Educandos mudos, apáticos e indiferentes ao ensino talvez sejam mais fadados ao fracasso do que os agitados. Como era próprio dos filósofos empiristas, o ato de conhecer exigia do aprendiz uma postura dinâmica diante daquilo que era oferecido. Só era possível conhecer a natureza a partir da intervenção direta da experimentação, da comprovação de hipóteses e da confirmação. Como o saber não era visto por Locke como uma capacidade inata, a aprendizagem só poderia advir da ação prática e, portanto, não contemplativa.

La curiosidad en los niños no es sino el apetito de conocimiento, y por consiguiente, debe ser estimulada, no solamente como un buen signo, sino como el gran instrumento que ha proporcionado la naturaleza para remediar la ignorancia con que nacemos, y sin ese espíritu de investigación seríamos criaturas torpes e inútiles (LOCKE, 1986, p. $169)^{13}$.

Estimular a curiosidade do aluno. Esta ideia não parece que foi escrita no século XVII, uma vez que existe hoje uma vasta bibliografia pedagógica recomendando aos professores que, antes de iniciar um conteúdo, procurem aguçar a curiosidade da criança ou do jovem para estimular um maior envolvimento do educando com o processo de ensino-aprendizagem. $\mathrm{O}$ educador tinha, na concepção lockeana de educação, uma grande responsabilidade em estimular o aluno para o conhecimento. A começar pelo tratamento 
que deveria dar às perguntas dos jovens e crianças, procurando responder a todas e tornado os assuntos complexos mais inteligíveis para eles. Ensinar temas diversos como se fossem a coisa mais importante do mundo, para que quem aprendesse, tomasse gosto pelo saber e quisesse repassá-lo a outras pessoas. O mestre não deveria nunca desdenhar da pergunta de seus aprendizes e muito menos dar-lhes respostas incompletas ou fantasiosas. Outra forma de instigar a curiosidade dos meninos era colocá-los diante de situações e objetos novos e diferentes do que estavam acostumados, "a fin de provocar sus investigaciones y darles ocasión de encariñarse com este asunto" (LOCKE, 1986, p. 171) ${ }^{14}$.

A valorização da experimentação prática e do espírito investigativo era essencial para uma proposta de educação empirista. Como o conhecimento não estava adormecido em nossas mentes como pensavam Platão e depois Descartes, era fundamental a prática como núcleo formador do homem. Para tomar posse do saber era preciso agir, cultivar o espírito científico, questionar as coisas e buscar as respostas. A razão não era vista como algo pronto e acabado no pensamento de Locke, daí a necessidade do exercício diário para desenvolvê-la e ampliar sua capacidade.

Porque después de todo, el razonamiento, que es la más elevada y la más importante facultad del espíritu, merece los mayores cuidados y debe ser cultivado con atención, puesto que el desenvolvimiento regular, el ejercicio de la razón, es la perfección más alta que el hombre puede alcanzar en la vida (LOCKE, 1986, p. 172) ${ }^{15}$.

Segundo Monroe (1979), Locke reiterou várias vezes em seus estudos a idéia de que a educação intelectual era uma formação do hábito de pensar, por meio da prática constante do exercício e da disciplina. O esforço para desenvolver nossa capacidade intelectual era uma forma de torná-la útil. Mais uma vez estava presente a obsessão pela questão da utilidade. O filósofo não admitia que algo que fosse cultivado e que houvesse o emprego de algum tipo de esforço humano, não tivesse certa finalidade. Era inconcebível perder tempo com alguma coisa que não pudesse ser empregada imediatamente. Mais uma vez podemos reconhecer no filósofo de Bristol um modelo de pensamento precursor da sociedade do capital.

Assim sendo, a instrução pela instrução para Locke não representava muita coisa. $\mathrm{O}$ mais importante era equipar o gentleman de instrumentos de intervenção na vida prática por meio do desenvolvimento de hábitos. De pouca valia era, para o mencionado autor, o estudo de gramática, latim ou retórica se a parte moral do jovem estava comprometida. A aquisição de conhecimentos por si só não levava o indivíduo a ter um papel atuante no meio em que estava inserido. Dessa forma, adquirir instrução era mais uma forma de consolidar hábitos e preparar o aluno para utilizar-se dos recursos de que dispunha da melhor forma possível.

La instrucción es necesaria, pero no se debe colocarse sino en segundo lugar, como un medio de adquirir cualidades más altas. Buscad, pues, alguno que sepa formar discretamente las costumbres de su discípulo; poned, pues vuestro hijo en tales manos que podáis, en la medida de lo posible, garantizar su inocencia, desenvolver y alimentar sus buenas inclinaciones, corregir dulcemente y curar las malas y hacerle adquirir buenos hábitos. Esto es el punto importante. Una vez que se haya conseguido, la instrucción puede ser adquirida por añadidura, $\mathrm{y}$, a mi juicio, en condiciones fáciles que es sencillo imaginar (LOCKE, 1986, p. $208)^{16}$. 
O conselho do pensador inglês expressava claramente sua ideia de uma educação disciplinadora, utilitária e instrumental, ou seja, um tipo de formação que estivesse mais adaptada aos novos tempos que o capital mercantil inglês estava trilhando. Era preciso deixar para trás o modelo rebuscado de ensino, baseado em métodos mnemônicos e contemplativos, para uma proposta de intervenção humana no mundo social e natural. $\mathrm{O}$ espírito autônomo, crítico e investigativo do gentleman eram as ferramentas essenciais para conduzir a um novo mundo, que estava no tempo de Locke, ainda em gestação.

\section{Considerações finais}

À primeira vista a obra de Locke pode parecer um inventário de propostas para a educação dos filhos da burguesia e da nobreza inglesa do século XVII que pouco tem a dizer sobre o ensino desenvolvido no Brasil. No entanto, retomando um pouco da recente história da nossa educação, no início do século XX, durante a chamada fase da República Velha, vamos perceber que havia dois modelos de escola, uma para a elite e outra para os trabalhadores. As classes mais abastadas teriam uma formação clássica ou científica de acordo com a sua opção, enquanto que a população em geral, se quisesse estudar, teria que frequentar as chamadas escolas profissionalizantes. Os cursos nas escolas técnicas eram de curta duração e privilegiavam a qualificação de mão de obra. A instrução mais formal resumia-se no domínio mínimo das habilidades de leitura e escrita e algumas noções de cálculo. Esta dicotomia entre ensino profissionalizante e formal continuou sendo cultivada nos períodos políticos seguintes e até hoje ainda é um problema mal resolvido no nosso sistema de ensino, principalmente agora com a criação dos cursos profissionais superiores de dois anos. Ao reconstituir essa trajetória histórica vamos entender melhor a gênese de muitos problemas na área da educação e seus desdobramentos.

De acordo com Eby (1976), Locke criou na Inglaterra um programa para profissionalizar os filhos de pais indigentes, como forma de retirá-los das ruas e ao mesmo tempo liberar as mães para que pudessem trabalhar nas fábricas desobrigando-as da responsabilidade de cuidarem das crianças. Em que pese uma contundente crítica ao espírito utilitarista do filósofo inglês, não se pode negar que ele tinha uma capacidade de pensar soluções para um mundo capitalista que ainda estava se constituindo. Na verdade, com esse projeto já podemos identificar a origem das primeiras creches, que tinham como objetivo liberar a mãe para que ela vendesse sua força de trabalho. Além disso, é preciso considerar que o salário da mulher era muito inferior ao do homem adulto e esta era uma forma inteligente de reduzir os custos de produção.

No que diz respeito diretamente às contribuições de Locke para o campo da educação, é preciso considerar suas críticas ao modelo de ensino que vigorava no século XVII, inadequado para as novas exigências materiais da sociedade que estava surgindo. Ao valorizar a curiosidade, a pesquisa empírica, a investigação e o despertar do senso crítico, o pensador parlamentarista trouxe uma nova perspectiva de se fazer educação, colocando o aluno como um agente ativo que interfere de maneira prática na natureza para ampliar a sua capacidade de raciocínio. Quanto à afirmação de que a razão só se fortalece à medida que é exercitada, Locke estava rompendo definitivamente com uma concepção dogmática de mundo.

Vários são as possibilidades que a análise do pensamento empirista do pai do liberalismo nos permite fazer, no entanto, é preciso não perder de vista o contexto histórico em que tudo isso acorreu. Caso contrário, corremos o risco de fazer uma interpretação que toma a idéia por si mesma sem se pensar no lugar onde ela lançou raízes. Ainda mais de um gênio como Locke que viveu com tanta intensidade seu tempo. 


\section{Referências}

EBY, Frederick. História da educação moderna. 2. ed. Porto Alegre: Globo, 1976.

ENGUITA, Mariano Fernández. A Face oculta da escola: educação e trabalho no capitalismo. Porto Alegre: Artes Médicas, 1989

FLORENZANO, Modesto. As revoluções burguesas. 7. ed. São Paulo: Brasiliense, 1986.

LAGO, Clenio. Locke e a educação. Chapecó: Argos, 2002.

LOCKE, John. Da dissolução do governo. In WEFFORT, F.C. (org). Os clássicos da política. 13. ed. São Paulo: Ática, 2002.

Dois tratados sobre o governo civil. São Paulo: Martins Fontes, 2004.

Ensaio acerca do entendimento humano. São Paulo: Nova Cultural, 1999.

Pensamientos sobre la educación. Madrid: Akal, 1986.

MANACORDA, Mario. História da educação. São Paulo: Cortez, 1994.

MELLO, Leonel Itaussu Almeida. Locke e o individualismo liberal. In WEFFORT, Francisco Correia (org). Os clássicos da política. 13. ed. São Paulo: Ática, 2002.

MONROE, Paul. História da educação. 14. ed. São Paulo: Companhia Editora Nacional, 1979.

\section{Notas}

\footnotetext{
${ }^{1}$ A obra de John Locke foi traduzida em partes por Avelino da Rosa Oliveira e Gumercindo Ghiggi com o título Alguns pensamentos acerca da Educação no periódico Cadernos de Educação da Universidade Federal de Pelotas (edições 18,019, 21 e 22).

${ }^{2}$ Ninguém está obrigado a saber de tudo. O estudo das ciências em geral é assunto daqueles que vivem bem e que dispõem de tempo livre. Os que dispõem de empregos particulares devem entender de suas funções e não é insensato exigir que pensem e raciocinem somente sobre aquilo que se refere a sua ocupação cotidiana.

${ }^{3}$ Segundo Lago (2002), Locke educou os filhos e os netos do conde de Shaftesbury. Quando foi para França dedicou-se à educação de John Banks, rico indivíduo do século XVII. Ainda no final da vida cuidou da aprendizagem de Francis Cudworth Masham e aconselhou a formação de muitos filhos de seus amigos. Seus alunos o descreviam como um homem erudito, mas também de senso prático.

${ }^{4}$ Quem quer que se ocupe da educação das crianças deverá estudar sua natureza e sua capacidade, [...] qual é sua inclinação dominante, [...] considerar o que a natureza deu às crianças, prevenir os vícios e os defeitos para os quais tal temperamento mais se inclina e procurar todas as vantagens que sejam capazes de receber. Deverá levar o gênio natural de cada criança tão longe quanto possa chegar. No entanto, tentar unir ao que já tem algo inteiramente diferente é desperdiçar seu esforço.

${ }^{5}$ Considerarei, consequentemente, como uma missão, o buscar a satisfação e o deleite e evitar a inquietude e a falta de comodidade; ter tanto do primeiro e tão pouco do segundo como seja possível.

${ }^{6}$ Se se encontra um menino ou uma menina, menores de quatorze anos de idade, mendigando fora da paróquia em que moram, se o fazem a uma distância de cinco milhas da dita paróquia, serão enviados à
} 
Escola de Trabalho mais próxima, e ali serão açoitados e entregues ao trabalho até a tarde, para ser dispensados com tempo suficiente para chegar em seu lugar antes da noite. Ou, se moram a mais de cinco milhas do lugar em que foram surpreendidos mendigando, serão enviados à casa de correção mais próxima e, ali permanecerão entregues ao trabalho seis semanas e ainda a sessões próximas depois de se terminar as seis semanas.

${ }^{7}$ Penso que se pode afirmar que de todos os homens com que tropeçamos, nove em cada dez são o que são, bons ou más, úteis ou inúteis, pela educação que receberam. Esta é a grande diferença entre os homens. As menores e mais indiferentes impressões que recebemos em nossa mais tenra infância têm consequências muito importantes e duradouras.

${ }^{8}$ Que a saúde é necessária ao homem para o manejo de seus negócios e para sua felicidade própria; que uma constituição vigorosa e endurecida pelo trabalho e pela fatiga é útil para uma pessoa que quer fazer um papel no mundo, é coisa demasiado óbvia para que necessite de alguma prova.

${ }^{9}$ Como a fortaleza do corpo consiste principalmente em ser capaz de resistir a fatiga, o mesmo ocorre com a do espírito. E o grande princípio ou fundamento de toda virtude e mérito se baseia nisto, em que um homem seja capaz de se esquivar da satisfação de seus próprios desejos, de contrariar suas próprias inclinações e seguir somente o que sua razão lhe dita como o melhor, ainda que o apetite o incline em outro sentido.

${ }^{10}$ Este método de ensinar as crianças mediante a prática repetida e a realização da mesma ação uma e outra vez, sob o olhar e a direção do tutor, até conseguir o hábito de fazê-lo bem, e não mediante regras confiadas a sua memória, têm tantas vantagens, por qualquer lado que se considere, que não posso deixar de me admirar (se podem admirar os maus costumes em qualquer coisa) de que chegue a se esquecer tanto.

${ }^{11}$ Esta classe de castigos não contribui em absoluto para diminuir nossa propensão natural à indulgência corporal e ao prazer presente e a evitar a dor a todo custo; pelo contrário a aumentam e fortificam em nós a disposição de onde brotam todas as ações viciadas, todas as irregularidades da vida.

${ }^{12}$ Se prevalece a severidade lavada a seus últimos limites e cura pelo momento um caráter destemperado, põe em seu lugar uma doença pior, todavia e mais perigosa que é a de quebrar os recursos do seu espírito. Então, em lugar de um jovem agitado, tereis uma criatura sem energia que, ainda quando, por sua sobriedade artificial agrade às pessoas artificiais que querem as crianças mudas e indolentes, porque não fazem nenhum barulho nem causam nenhuma moléstia, nem se deixará parecer aos seus amigos um ser incômodo e que, em efeito, durante toda sua vida será um ser inútil para si mesmo e para os demais.

13 A curiosidade nas crianças não é senão o apetite de conhecimento e, consequentemente, deve ser estimulada, não somente como um bom sinal, senão como o grande instrumento que nos há proporcionado a natureza para remediar a ignorância com que nascemos. Sem esse espírito de investigação nos tornamos seres torpes e inúteis.

${ }^{14}$ [...] a fim de provocar suas investigações e dar-lhes ocasião de afeiçoar-se com este assunto.

15 Porque depois de tudo, o raciocínio, que é a mais elevada e a mais importante faculdade humana do espírito, merece os maiores cuidados e deve ser cultivado com atenção, uma vez que o desenvolvimento regular, o exercício da razão, é a perfeição mais alta que o homem pode alcançar na vida.

${ }^{16}$ A instrução é necessária, porém não deve colocar-se senão em segundo lugar, como um meio de adquirir qualidades mais elevadas. Busca-te, pois algum (preceptor) que saiba formar discretamente os hábitos de seu discípulo, ponha-te, pois vosso filho em tais mãos que podeis, na medida do possível, garantir sua inocência, desenvolver e alimentar suas boas inclinações, corrigir docemente e curar as más e fazer-lhe adquirir bons hábitos. Este é o ponto importante. Uma vez que tenha conseguido, a instrução pode ser adquirida por complemento e a meu ver, em condições fáceis que é simples imaginar.

Recebido em março/2012

Aprovado em julho/2012 